[DOI: 10.24214/jecet.A.9.4.60121.]

Jaurnal of Environmental Science, Computer Science and Engineering \& Technology

An International Peer Review E-3 Journal of Sciences and Technology

Available online at www.jecet.org

Section A: Environmental Science

Research Article

\title{
The guidelines for raising up and developing effective educational organization in small schools' spread to students' education asylum and schools' dissolution of local schools' crisis in Thailand
}

\author{
${ }^{1}$ Teerapol Pengchan \& ${ }^{2}$ Toansakul Tony Santiboon \\ 1Development of Educational Administration, Faculty of Education, Udon Thani \\ Rajabhat University, Thailand \\ 2 Research and Postgraduate Administrator (18/106935), Queen's University Belfast, \\ Northern Ireland, UK.
}

Received: 10 August 2020; Revised: 24 August 2020; Accepted: 02 September 2020

\begin{abstract}
This study was to investigate the guidelines for raising up the quality enhancement to synthesis the Office of Bueng Kan Primary Education Service Area in 122 small schools with the 500 officers/personnel educators' (OPS) perceptions from 9 Districts with the participators were administered. Designing the correlation variables with the 42-item Factors on Efficient Public Sector Management (FEPSM) Questionnaire on 7 scales were assessed the officials' efficient public sector administrative management organizations. The Thai education failure and small school crisis of Thai government policy reforms to spread of students' asylums and dissolutions were assessed with the 35-item Questionnaire on Thai Education Policy (QTAP), and the 10-item Teacher-Student Creative Thinking Abilities (TSCTA) that was violence against teachers and students' instructional skills were analyzed with the inference statistic. The three instruments are valid and reliability with the Cronbach alpha coefficient, intercorrelation circumplex, and factor loading analysis. Learning and teaching management of small schools alone, lonely, and abandoned under the failure of educational administration and management according to the policy of the
\end{abstract}


governances with the same action model in 2016-2019, decreasingly. The $R^{2}$ values indicated that of $60 \%$ and $82 \%$ of the OPSs' opinions who need to develop the characteristic of small school organization and to claim from the government policy acceleration on solving problems for the FEPSM and QTAP. Statistically significant with the simple and multiple correlations are positive direction, linear regress is predicted on correlation variables, and determination predictive values $\left(R^{2}\right)$ indicated that of $40 \%$ and $36 \%$ of the variance for the OPEs of the proportion in the dependent variable as the TSCTA that is predictable from the independent variables as the FEPSM and QTEPR scales, respectively on the guidelines for raising up and developing effective educational organization to spread of students' educational asylum and schools' dissolution of rural small schools' crisis.

Keywords: Educational policy failure, Thai education system, administration and management, small schools spread, the asylum and dissolution, the local schools' crisis, the Buengkan Primary Education Service Area Office

\section{INTRODUCTION}

Reforms needed to fix Thai schools: Thailand's education reform still has a long way to go despite it being a key element of the military regime's efforts to propel the country out of the middle-income trap after it seized power ${ }^{[1]}$. When the National Council for Peace and Order (NCPO) seized power in May 2014, its supposed mandate was to eliminate corruption, the political conflict, and reform Thailand's failing social institutions ${ }^{[2]}$.

The National Core Curriculum for Basic Education 2016: Thailand's curriculum is outdated and overloaded. A complete overhaul in terms of teaching literacy and numeracy, achieved in other countries by hiring experts from more successful countries, is required to ensure children master the basics before focusing on the development of higher thinking skills. The current O-Nets are still poorly written, insular, multiple-choice assessments which focus only on testing lower-order thinking skills. The NCPO has failed to provide education reforms that would benefit children. In terms of educational rights students' asylum at the local schools under the Ministry of Education and Thai government policy reforms in the $21^{\text {st }}$ century, despite this, concerns have been raised with the primary school students' asylum determination processes ${ }^{[3]}$.

Rural Education under the Primary Educational Service Area Office (OBEC): There are 8 strategies to the operation of democratic promotion in educational institutions consisted that include promoting democratic learning for all personnel within education institutions. The planning of democratic promotion in educational institutions with participation, the systematic approach to democracy promotion in educational institutions to improve the processing of monitoring and assessment to accelerate the implementation of the program for encouraging the implementation of democratic processes to integrate learning management ${ }^{[3]}$.

Educational inequality in rural schools, eliminating inequality in education is an urgent policy of the Ministry of Education. In the past, the quality of education in Thailand has remained almost double the gap between the knowledge of urban students and rural students. One of the reasons is due to the quality or standard of the school. Including the quality and efficiency of teachers, which directly affects student learning, for supporting the development of primary schools under the OBEC in rural areas with children and youth who lack funds or underprivileged and underprivileged people are crowded to be a school that can continuously improve quality systematically. To provide students with learning skills 
these are in line with the 21 st century and have a higher academic achievement to help students individually ${ }^{[4]}$.

Importantly, administrators and teachers are ready to voluntarily develop. Which if these leading schools have been improved the quality of learning for the students in the whole school systems with teachers being the key drivers which will result in higher learning the efficiency of students in the future will be integrated with the quality schools of the sub-district OBEC. In the long run, this project will create a model for school quality reform to reduce inequality. Wish all schools Office of Primary Educational Service Area to cooperate fully with the OECD and network partners in the development of teachers and schools in accordance with the project guidelines.

The main ideas of this project must start from the administrators and teachers. There is a belief that this can improve themselves and the schools. Even though it is a school that is far away or not a large school is able to develop until progress without having to wait for external help or policies. Therefore, the result in administrative reform and teaching in the whole school system of their working in the first year, there will be a medium-sized school where administrators and teachers voluntarily, and intend to participate in a total of 288 locations in 35 provinces in every region, covering over 5,700 teachers. The development is divided into 2 levels: class level and school level ${ }^{[5]}$. Cooperation between the OBEC and the GFS, this time will make another 80 percent of children to 90 percent to receive the opportunities to develop and achieve life goals as well ${ }^{[6]}$.

Although education in Thailand mandates nine years of "basic education" (six years of elementary school and three years of lower secondary school). Education in public schools is free until grade 9. The government provides, in addition, three years of free pre-school and three years of free uppersecondary education. As long as the focus is on smartest students in a few select schools, educational inequality \& low test scores for the country overall will be the result ${ }^{[7]}$.

One major aspect of Thailand's education failure is that students in Bangkok and large cities receive better schooling than students in rural schools, which are far below the national average. Teachers are selected from the top $10 \%$ of the country's graduates. They are required to earn a master's degree in education. The problem of inequality is more pressing for small primary schools and secondary schools. Each small school has less than 20 students in each grade, in rural areas. Small schools lack both sufficient state funding, as well as the teachers, needed to increase the quality of teaching and the performance of students ${ }^{[8]}$.

Thailand's education reform still has a long way to go despite it being a key element of the military regime's efforts to propel the country out of the middle-income trap after it seized power. Despite all the lofty goals and tremendous effort made to improve the state of Thai education recently. It's supposed mandate was to eliminate corruption, the educational conflict, and reform Thailand's failing social institutions for improving the education system was prioritized as a key element in the government's ambitions to propel Thailand out of the middle-income trap and toward "Thailand 4.0" [9].

Small schools have many problems. Many parties said it was natural or the Thai Government also says that they don't die or raise up. It's a sign that small schools are aware of how to adapt to survive. It can be seen from the news about the movement of small schools. Ministry of Education Announcement of the Basic Education Financial Reform Strategy by dissolving about 7,000 smaller schools out of 15,000 by the year 2018, there has been concern from the Education Reform Policy Committee in the second decade (PMD), don't want to use the word "collapse" because it causes society to misunderstand that there will be a collapse of all small schools which in truth was not collapsed but they will use management that will increase the quality and efficiency of teaching and learning ${ }^{[10]}$. 
The private schools whereas educational right students' asylum for rural students: Private schools can alleviate the burden of government on education management for youth, which has both formal education and non-formal education allowing the state to save a lot of money on education investments. Most private schools are schools located in almost every community. Considered as a school is near students' homes and supporting convenient transportation. Therefore, to be able to attract the attention of students and parents are comfortable. In terms of convenience and time-saving include transportation costs for students are going to schools and pick return back to their homes, simplify ${ }^{[11]}$.

As above these are the reasons for the rural parents are selected for their students why have educational right of the students' asylum been of pre-schools and primary-school students? These situations are affected by the Thai education failures toward Thai government policy reforms aren't spread of dissolution in the local schools' crisis, unsuccessfully ${ }^{[12]}$.

The Office of the Basic Education Commission (OBEC) is a Thai governmental agency, founded in 2003. It is an office of the Thai Ministry of Education (MOE). Its mission is to organize and promote basic education from primary school to secondary school. Bueng Kan Province is the Bueng Kan Basic Primary and Secondary Educational Service Area Office. In this research study was focused on the small-sized in the schools consist of less than 120 students at the Office of Buengkan Primary Education Service Area ${ }^{[13]}$.

There are 212 primary schools under the Office of Buengkan Primary Education Service Area throughout in the 9-district. The accounting primary educational teachers consist of 3,010 teachers, 39,610 primary students, and 2,203 classrooms. In terms of the small-sized school obtains as 80 schools; the accounting student range from 0 to 120 students ${ }^{[14]}$. Because there are 305 small-sized schools at the Office of Buengkan Primary Education Service Area has too many problems, so the Thai Government policy on the dissolution of small-sized schools in Bueng Kan Province (Figure 1).

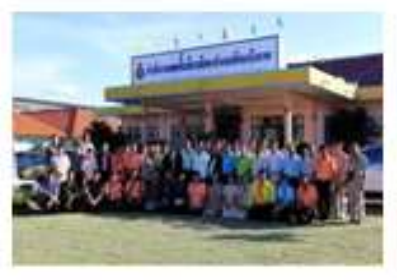

(a)

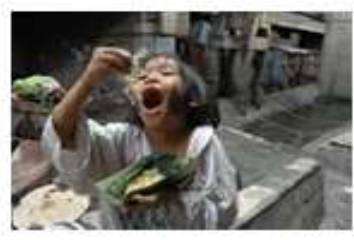

(e)

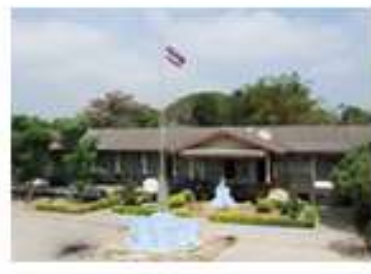

(b)

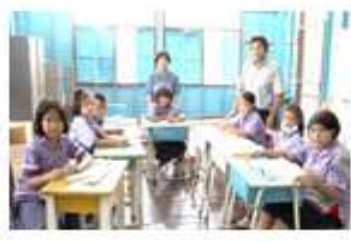

(f)

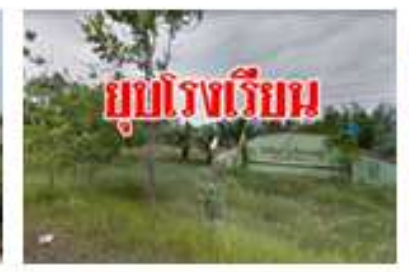

(c)

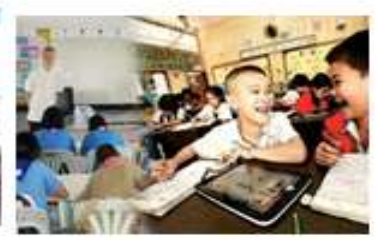

(g)

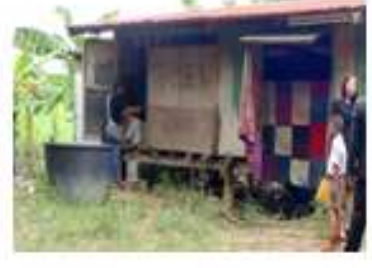

(d)

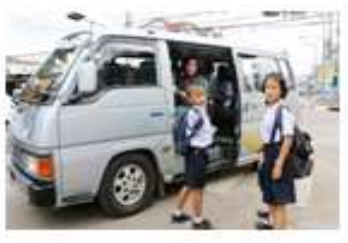

(h)

Figure 1: The Office of Buengkan Primary Education Service Area (a), Small-sized school environment (b). Government policy on the schooling dissolution (c), Some children leave out from school according to their families are poorly to cover related expenses for their staying and food ( $\mathrm{d}$ and e), Differentiated between the rural and city school classroom environments ( $\mathrm{f}$ and g), Vans transport students from their village to the schools in the city: This is the educational asylum for students (h) Source: The Office of Buengkan Primary Education Service Area $(2018)^{[15]}$ 


\section{Bueng Kan Province}

Bueng Kan is the $76^{\text {th }}$ province of Thailand, established by the Act Establishing Bueng Kan Province, in 2011 on 22 March 2011. The province is in the northeastern region of the Kingdom of Thailand ${ }^{[16]}$. The borders are with the Mekong River forming the boundary, which means "Lonely Mountain." The province is divided into nine districts. The districts are further subdivided into 53 sub-districts and 615 villages, namely; Mueang Bueng Kan, Phon Charoen, So Phisai, Seka, Pak Khat, Bueng Khong Long, Si Wilai, and Bung Khla districts ${ }^{[17]}$ (Figure 2).

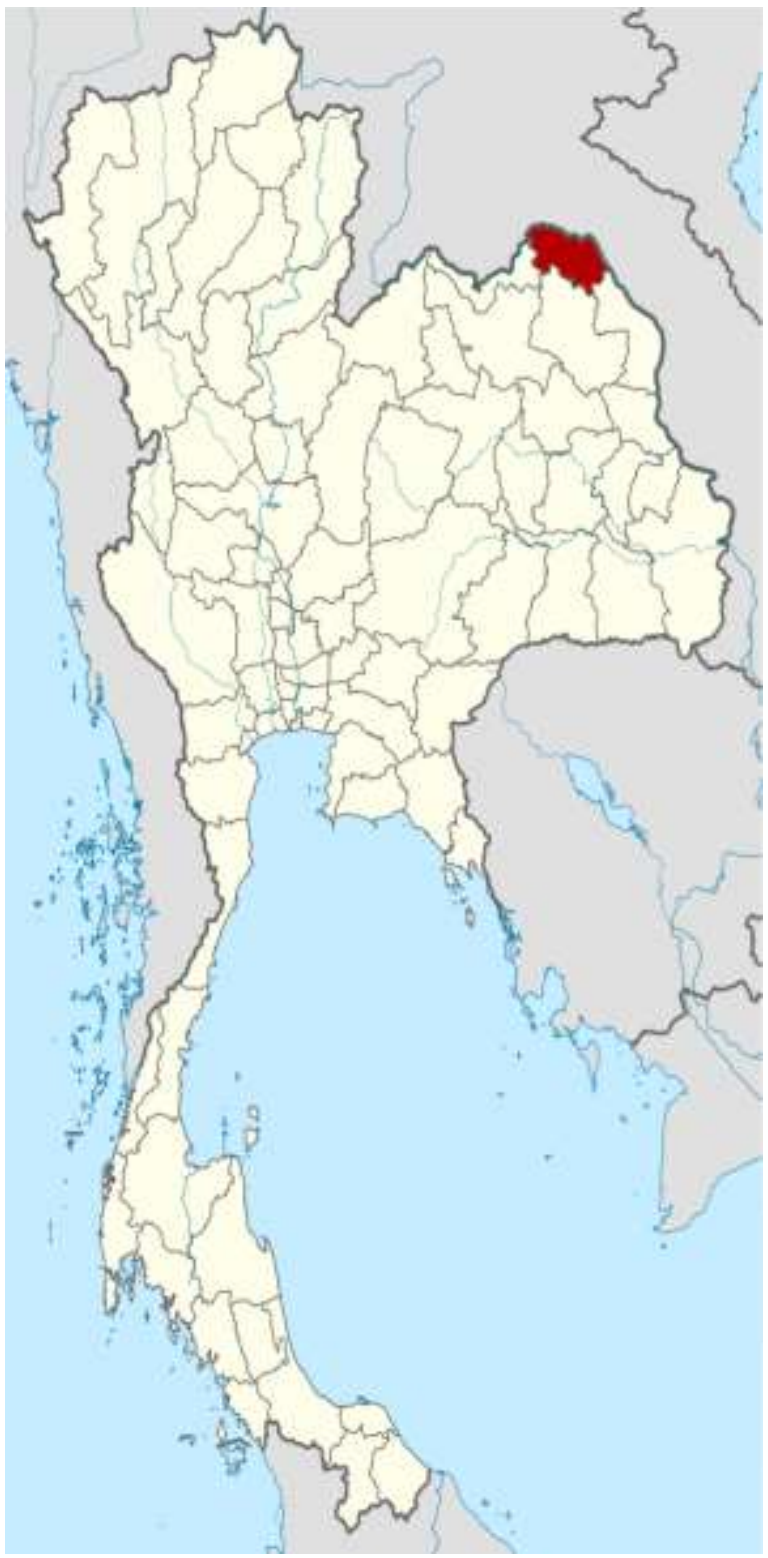

a) Map of Bueng Kan Province

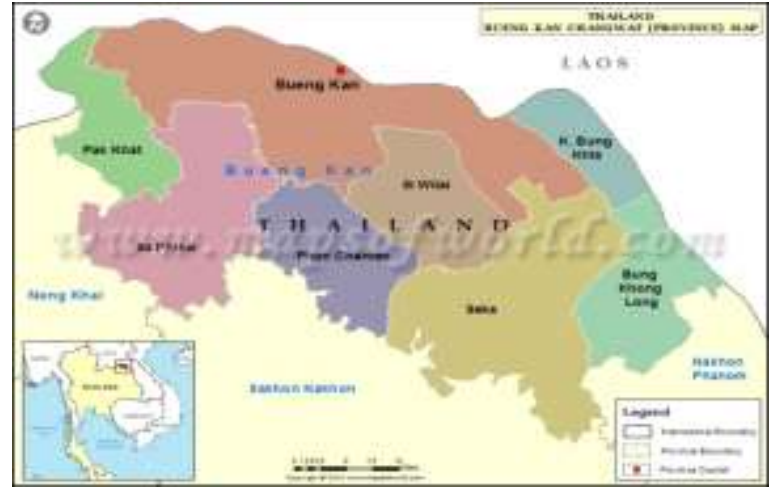

b) BuenKan Province geographical location border

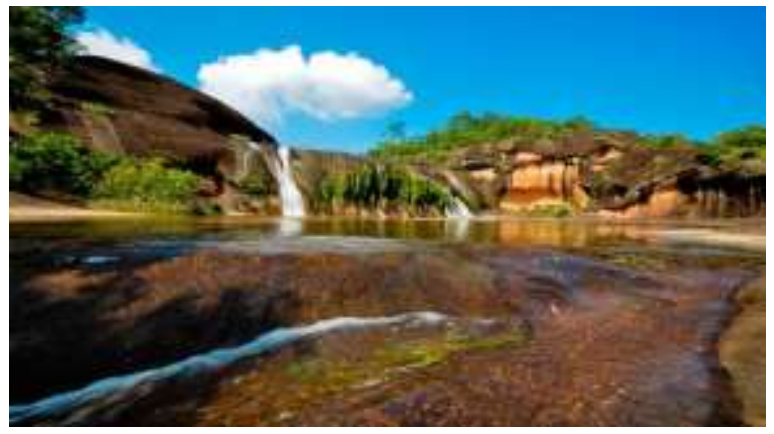

c) Unseen Thaiand at Bueng Kan Province; The most spectacular (Phu Wua Wildlife Sanctuary)

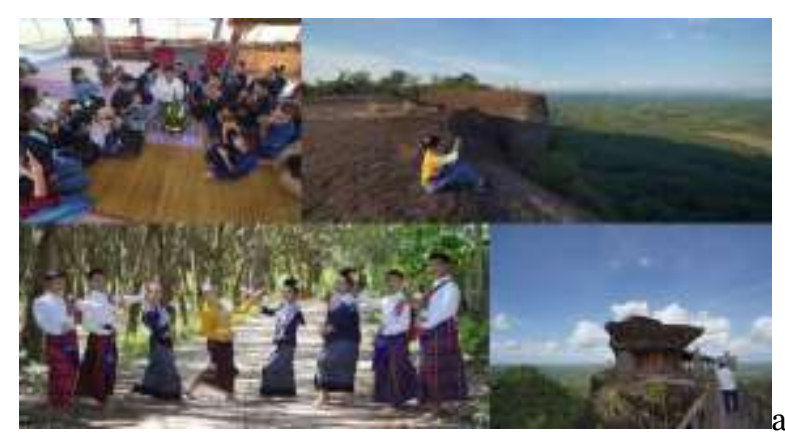

d) Local tradition and regulation fairness

Figure 2: Map of Bueng Kan Province (a), BuenKan Province geographical location border (b), Unseen Thaiand at Bueng Kan Province (c and d) 


\section{MARTIAL'S AND METHODS}

The designing instructional model with the educational right political asylum of primary school students, that effective Thai education failure of Thai government reform policies to spread of dissolution in the rural schools' crisis according to the failures of Thai educational administration and management were examined. Focused on small schools spread to the dissolution with the guidelines for raising up the quality enhancement according to development synthesis of the Bueng Kan Primary Education Service Area Office was assessed into five theoretical frameworks that following as:

\section{Research Objectives}

1. To analyze the factors on efficient public sector management at the current conditions, problems, and needs of the administrations of small schools in the Bueng Kan Primary Educational Service Area Office are assessed with the Factors on Efficient Public Sector Management (FEPSM) questionnaire.

2. To synthesis the developing guidelines for raising up the quality enhancing Thai education reform policy according to the Bueng Kan Primary Educational Service Area Office is assessed with the Questionnaire on Thai Education Reform Policy (QTEPR).

3. To assess the officers' and personnel educators' perceptions of teachers' and students' creative thinking abilities in instructional classroom environments of the small schools in the Bueng Kan Primary Educational Service Area Office with the Teacher-Student Creative Thinking Ability (TSCTA) scale.

4. 1To associate between the factors on efficient public sector management perceptions and their teachers' and students' creative thinking abilities in instructional classroom environments of the small schools in the Bueng Kan Primary Educational Service Area Office.

5. To associate between the perceptions of the officers' and personnel educators' developing guidelines for raising up the quality enhancing Thai education reform policy and the teachers' and students' creative thinking abilities in instructional classroom environments of the small schools in the Bueng Kan Primary Educational Service Area Office.

\section{Research instruments}

\section{The Factors on Efficient Public Sector Management (FEPSM) Questionnaire}

The FEPSM has 7 scales with each scale containing six items. The scales of the FEPSM are Change Management (ChM), Strategy/Risk Changes (SRC), Efficiency/Effective Plan by Government (EEPG), Leadership Change (LeC), Service Recipients/Stakeholders (SRS), Development Personnel (DeP), and Characteristic Organization (ChO) was the guideline for developments to the effective educational organization in the Bueng Kan Primary Educational Service Area Office that focused on the 122-small schools' administration was affected by public sector management.

\section{The Questionnaire on Thai Education Reform policy (QTAPR)}

This instrument is appropriate for the primary small schools which contain 35 items and five scales which are Education Reform policy (EPR), Guidelines Raising up Quality (GRQ), Educational Instructive Integration (EII), Right Students' Asylum (RSA), and Material/Technology Environment (MTE) was assessed the Thai education failure and school crisis of Thai government reform policies to spread of dissolution in the rural schools' crisis. 


\section{The Teacher-Student Creative Thinking Ability (TSCTA) Questionnaire}

Officers' perceptions of personnel educators to the teachers and students who were participated in instruction at the 122 small schools to their creative thinking abilities were assessed with the TeacherStudent Creative Thinking Ability (TSCTA) with 10 items.

Most of three instruments have five response alternatives are Very Disagree (1), Disagree (2), Neither Disagree nor Agree or Somewhat Agree (3), Agree (4), and Very Agree (5) that is presented in Appendix C ${ }^{[18]}$.

\section{Educational Participations}

The eleven agencies in nine districts of Bueng Kan Province who was the sample size of 500 personnel with the purposive random sampling for probability sampling was selected in the academic year 2019.

\section{Data Analysis}

An interview was the most important source of data of this study. Statistically significant were analyzed with the foundational and inference statistics, such as; Simple and Multiple Correlations, Standardized Regression Weight Validity $(\beta)$, and Coefficient Determinant Predictive Value $\left(\mathrm{R}^{2}\right)$ was associated.

Most of the research instruments were assessed the officers and personnel educators of the guideline for development to the effective educational organization in the Bueng Kan Primary Educational Service Area Office that focused on the 122-small schools' administration was affected by public sector management, and teacher-student creative thinking abilities of their instructions to their classroom environments was associated.

\section{RESULTS}

\section{Qualities and opportunities of primary students at the small-sized schools}

Educational reform found an important point in driving education reform, namely the quality and opportunity of learners, with one important reason for the quality and opportunity of the learners, that is, small schools (each school has less than 120 students). Office of Bueng Kan Primary Educational Service Area is an agency whose mission is to manage basic education; there are 212 schools in charge. There is only one school without student, 80 small schools, or $37.74 \%$ of all schools throughout Bueng Kan Province

Table 1: Shows the accounting number of small schools during the academic year 2016-2019

\begin{tabular}{|c|c|c|c|c|c|}
\hline Academic year & $\begin{array}{l}\text { Accounting } \\
\text { schools }\end{array}$ & overall & $\begin{array}{l}\text { Accounting } \\
\text { sized school }\end{array}$ & small- & Percentage \\
\hline 2016 & 214 & & 81 & & 37.9 \\
\hline 2017 & 214 & & 78 & & 36.4 \\
\hline 2018 & 213 & & 77 & & 36.2 \\
\hline 2019 & 212 & & 80 & & 37.7 \\
\hline
\end{tabular}




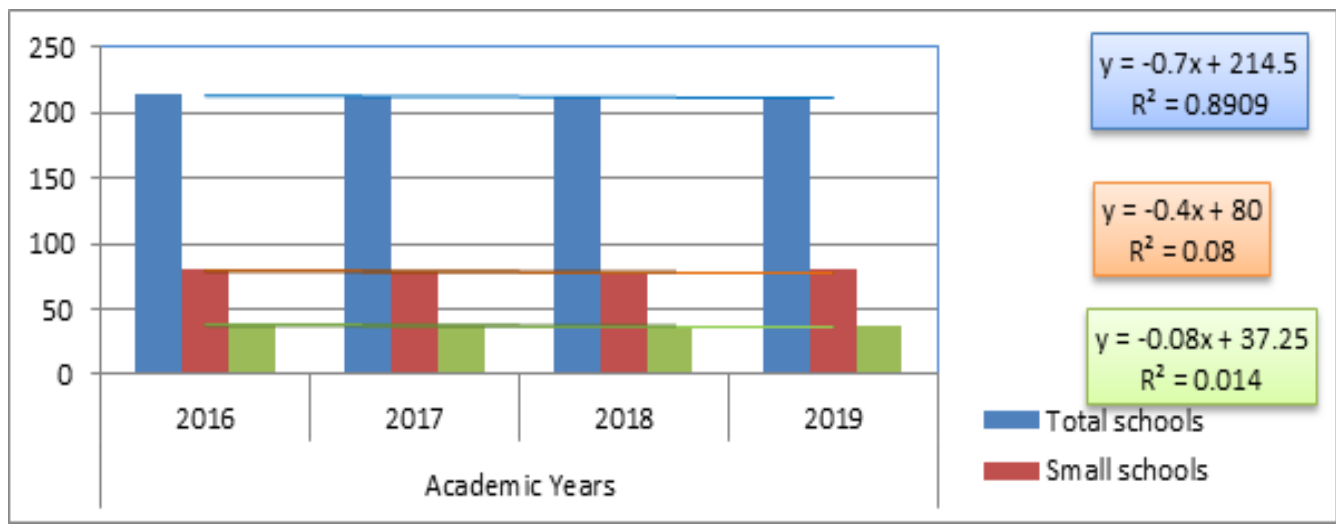

Fig. 1: Comparison between the total and small school sized with gap of percentage in the academic year 2016-2019

As reported in Table 1 and Figure 1, it meanwhile, as the slopes relatively are shown in negative decreasing value of the associations between accounting numbers in four academic years are decreased, significantly. The $\mathrm{R}^{2}$ values indicated that of $9 \%, 8 \%$, and $1 \%$, respectively that the $\mathrm{R}^{2}$ values of the variance in each academic year to the account number, small schools were attributable to their accounting numbers in each academic year, decreasingly.

Table 2: Accounting number of Number of students in small schools during academic year 2016-2019

\begin{tabular}{llllll}
\hline $\begin{array}{l}\text { Academic } \\
\text { year }\end{array}$ & $\begin{array}{l}\text { Accounting } \\
\text { Students No. }\end{array}$ & $\begin{array}{l}\text { Accounting } \\
\text { Teachers No. }\end{array}$ & $\begin{array}{l}\text { Accounting } \\
\text { classroom No. }\end{array}$ & $\begin{array}{l}\text { Teacher: } \\
\text { student rated }\end{array}$ & $\begin{array}{l}\text { Classroom: } \\
\text { student rated }\end{array}$ \\
\hline 2016 & 5,563 & 448 & 632 & $1: 12$ & $1: 9$ \\
2017 & 5,328 & 404 & 609 & $1: 13$ & $1: 9$ \\
2018 & 5,267 & 417 & 598 & $1: 13$ & $1: 9$ \\
2019 & 5,539 & 453 & 638 & $1: 13$ & $1: 9$ \\
\hline
\end{tabular}

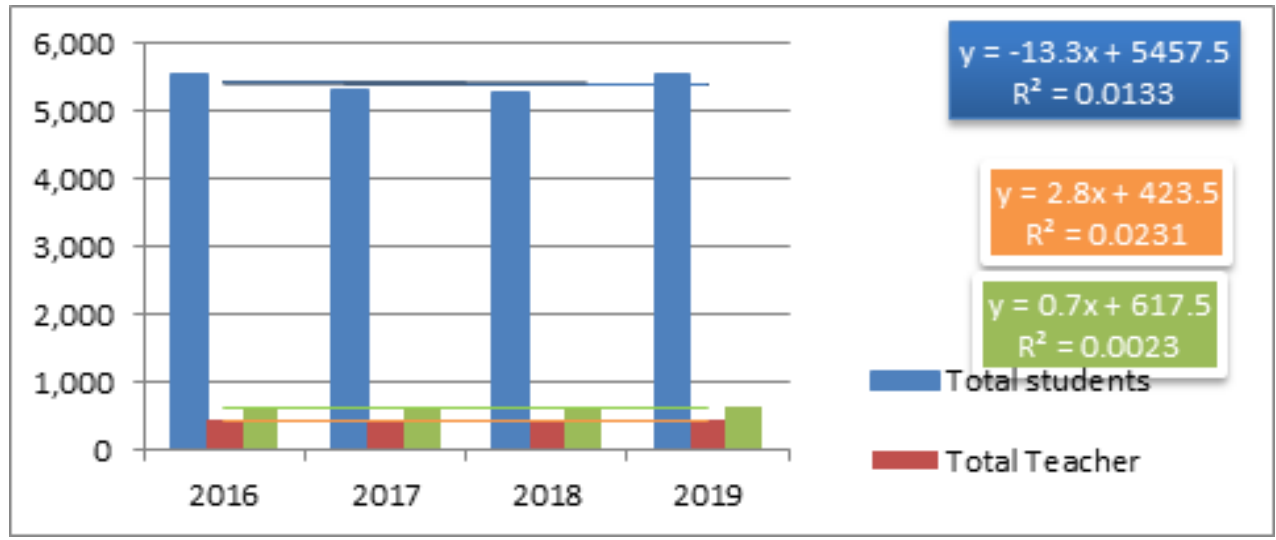

Fig. 2: Comparisons between total students, teachers, and classroom learning in the small schools with linear equation and determination efficient predictive $\left(R^{2}\right)$ values 
Table 2 and Figure 2 were reported as linear equations. Meanwhile, as the slopes relatively are shown in negative value on the association between accounting numbers and accounting students in four academic years are decreased, significantly. The $\mathrm{R}^{2}$ values on the accounting teachers and classroom numbers indicate that of $1.3 \%, 2.3 \%$, and $0.2 \%$, respectively.

Table 3: Accounting Number of small schools that classified by accounting number of students in 2016-2019

\begin{tabular}{lllll}
\hline Accounting No. of & \multicolumn{4}{l}{ Accounting No. of the small schools for each academic year } \\
\cline { 2 - 5 } students & 2016 & 2017 & 2018 & 2019 \\
\hline Less than 10 student & 0 & 0 & 2 & 1 \\
Less than 20 students & 4 & 3 & 4 & 2 \\
$21-40$ students & 9 & 7 & 6 & 10 \\
$41-60$ students & 20 & 21 & 21 & 21 \\
$61-80$ students & 22 & 19 & 19 & 18 \\
$81-120$ students & 26 & 26 & 27 & 29 \\
\hline Average students & 13.5 & 12.7 & 13.2 & 13.5 \\
\hline Total & 81 & 76 & 79 & 81 \\
\hline
\end{tabular}

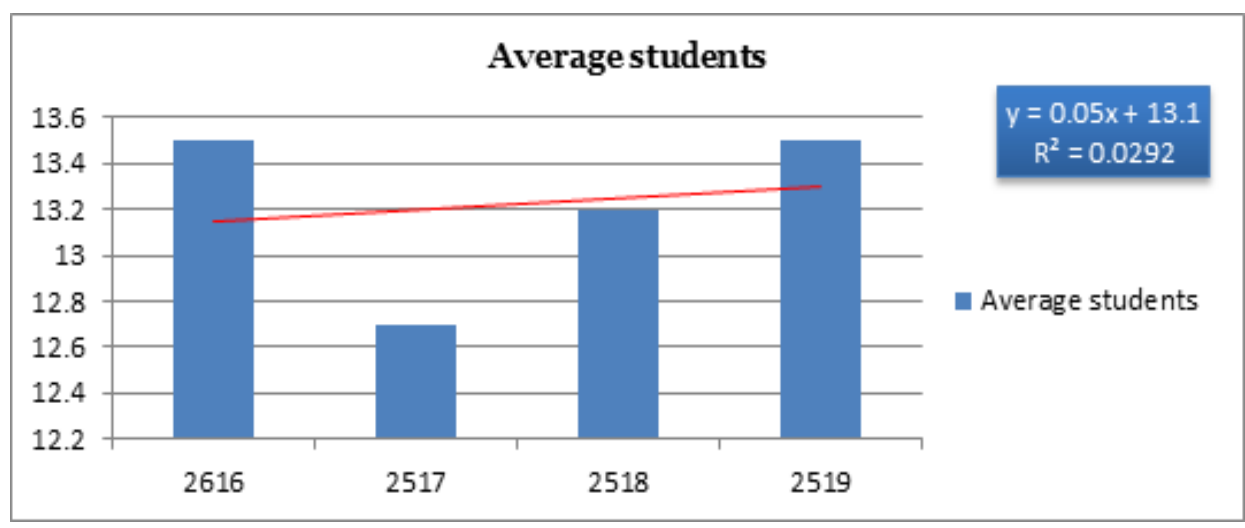

Fig. 3: Comparisons between total average students in the small schools with linear equation and determination efficient predictive $\left(R^{2}\right)$ values

Table 3 and Figure 3 reported the linear equations between the academic years (y) and average smallsize students (x). The slops relatively are shown in positive value on the association are increasing, significantly. The $\mathrm{R}^{2}$ values indicated that of $2.9 \%$ of the variance in the academic years to the accounting numbers of students in each academic year to the accounting student numbers in the small schools were attributable, in a little increasingly.

To analyze the factors on efficient public sector management at the current conditions, problems, and needs of the administrations of small schools in the Bueng Kan Primary Educational Service Area Office are assessed with the Factors on Efficient Public Sector Management (FEPSM) 
Table 4: The Scale Mean, Item Mean, Standard Deviation, Variance, Cronbach Alpha Reliability, and F-test for the Seven Scales of the FEPSM

\begin{tabular}{|c|c|c|c|c|c|c|}
\hline Scale & $\begin{array}{l}\text { Scale } \\
\text { mean }\end{array}$ & $\begin{array}{l}\text { Item } \\
\text { mean }\end{array}$ & $\begin{array}{l}\text { S.D. } \\
\text { (Scale } \\
\text { Mean) }\end{array}$ & Variance & $\begin{array}{l}\text { Alpha- } \\
\text { reliability }\end{array}$ & F-test \\
\hline Change Management (ChM) & 19.742 & 3.290 & 3.210 & 10.304 & 0.803 & $3.596^{* *}$ \\
\hline Strategy/Risk Changes (SRC) & 19.814 & 3.302 & 3.144 & 9.887 & 0.797 & $9.140 * * *$ \\
\hline Efficiency/Effective Plan by & 19.556 & 3.259 & 3.353 & 11.245 & 0.842 & $7.254 * * *$ \\
\hline \multicolumn{7}{|l|}{ Government (EEPG) } \\
\hline Leadership Change (LeC) & 19.626 & 3.271 & 3.222 & 10.383 & 0.821 & $2.950 *$ \\
\hline Service & 19.934 & 3.322 & 3.204 & 10.266 & 0.796 & $14.556^{* * *}$ \\
\hline \multicolumn{7}{|l|}{ Recipients/Stakeholders (SRS) } \\
\hline Development Personnel (DeP) & 20.248 & 3.375 & 3.053 & 9.321 & 0.728 & $16.274 * * *$ \\
\hline $\begin{array}{l}\text { Characteristic Organization } \\
(\mathrm{ChO})\end{array}$ & 20.288 & 3.381 & 3.053 & 9.321 & 0.766 & $4.712 * * *$ \\
\hline
\end{tabular}

$N=500,{ }^{*} \rho<0.05,{ }^{* *} \rho<0.01,{ }^{* * *} \rho<0.001$

The scale means ranged from 19.556 (Efficiency/Effective Plan by Government (EEPG) scale to 20.288 (Characteristic Organization $(\mathrm{ChO})$ scale, the item mean is ranged from 3.259 to 3.381, Standard Deviation with the scale mean is ranged from 3.053 to 3.353, Variance is ranged from 9.321 to 11.245 , Cronbach Alpha Reliability is ranged from 0.728 to 0.842, and F-test is ranged from $2.950(p<.05)$ to $16.274(p<.001)$ for the Seven Scales of the FEPSM. On the whole, these results are acceptable although somewhat lower than obtained previously validation sample that the results as reported in Table 4.

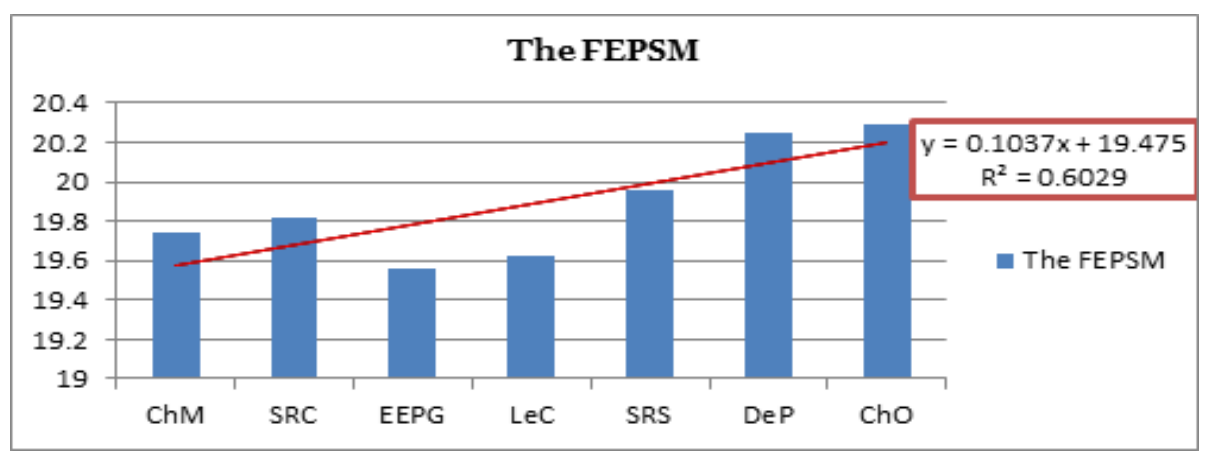

Fig. 4: The pictorial comparisons between seven scales of the factors on efficient public sector administrative management to the guidelines for raising up and developing effective educational organization in small schools' spread to the dissolution of local schools' crisis administration

The sample size's responses as $60 \%$ of the 500 officers and personnel educators' perceptions who need to develop the characteristic ( $\bar{x}=3.381$ ) of small school organization at the first. According to the development personnel $(\bar{x}=3.375)$, service recipients/stakeholders $(\bar{x}=3.322)$, strategy and risk 
changes ( $\bar{x}=3.302$ ), change management ( $\bar{x}=2.290)$, leadership change $(\bar{x}=2.290)$, and efficiency and effective plan by the government $\left(\bar{x}=2.290\right.$ ) was analyzed on the first research objective. The $\mathrm{R}^{2}$ values indicated that of $60 \%$ of the 500 officers and personnel educators' opinions that need to develop the small school characteristics.

Table 5: Scale Intercorrelation Circumplex Nature for the FEPSM

\begin{tabular}{llllllll}
\hline & ChM & SRC & EEPG & LeC & SRS & DeP & ChO \\
\hline ChM & & & & & & \\
SRC & $0.690^{* * *}$ & & & & & \\
EEPG & $0.657^{* * *}$ & $0.728^{* * *}$ & & & & \\
LeC & $0.653^{* * *}$ & $0.712^{* * *}$ & $0.767^{* * *}$ & & & \\
SRS & $0.657^{* * *}$ & $0.670^{* * *}$ & $0.680^{* * *}$ & $0.736^{* * *}$ & & & \\
DeP & $0.593^{* * *}$ & $0.522^{* * *}$ & $0.562^{* * *}$ & $0.551^{* * *}$ & $0.533^{* * *}$ & & \\
ChO & $0.52^{* * *}$ & $0.469^{* * *}$ & $0.515^{* * *}$ & $0.497^{* * *}$ & $0.508^{* * *}$ & $0.701^{* * *}$ & \\
\hline
\end{tabular}

*** Correlation is significant at the o.oo1 level (2-tailed).

As expected, the results in Table 5 show that the correlation between a scale and the next scales with the item means in general. This is illustrated using each scale, the circumplex natures of the FEPSM has been confirmed, significantly $(\mathrm{p}<.001)$.

The factor structure that emerged replicated, to a large extent. Table 6 list the items in seven scales which were found to validity, intercorrelation circumplex significantly $(\mathrm{p}<.001)$, and to have factor loading greater than 0.30 (which is the minimum value conventionally accepted as meaningful in factor analysis).

Overall, the summary of these values obtained separately for the FEPSM are reported in Table 4, 5 and 6 revealed that the seven scales of the FEPSM were statically significant at the .05 level for further satisfactory in this research study is confirmed.

Table 6: Factor Loadings for Items in the Seven Scales for the FEPSM

\begin{tabular}{|c|c|c|c|c|c|c|c|}
\hline Item No. & ChM & SRC & EEPG & LeC & SRS & $\overline{\mathrm{DeP}}$ & $\mathrm{ChO}$ \\
\hline 2 & 0.808 & & & & & & \\
\hline 3 & 0.781 & & & & & & \\
\hline 5 & 0.716 & & & & & & \\
\hline 4 & 0.679 & & & & & & \\
\hline 6 & 0.660 & & & & & & \\
\hline 1 & 0.594 & & & & & & \\
\hline 12 & & 0.772 & & & & & \\
\hline 8 & & 0.759 & & & & & \\
\hline 11 & & 0.700 & & & & & \\
\hline 10 & & 0.691 & & & & & \\
\hline 7 & & 0.685 & & & & & \\
\hline 9 & & 0.619 & & & & & \\
\hline 13 & & & 0.810 & & & & \\
\hline 14 & & & 0.809 & & & & \\
\hline 16 & & & 0.751 & & & & \\
\hline 15 & & & 0.711 & & & & \\
\hline 18 & & & 0.702 & & & & \\
\hline 17 & & & 0.700 & & & & \\
\hline
\end{tabular}

611 JECET; September 2020- November 2020; Sec. A; Val.9. No.4, 601-621. DOI:10.24214/jecet.A.9.4.60121. 


\begin{tabular}{|c|c|c|c|c|c|c|}
\hline 22 & & & 0.798 & & & \\
\hline 24 & & & 0.751 & & & \\
\hline 20 & & & 0.751 & & & \\
\hline 19 & & & 0.718 & & & \\
\hline 23 & & & 0.698 & & & \\
\hline 21 & & & 0.643 & & & \\
\hline 26 & & & & 0.748 & & \\
\hline 25 & & & & 0.724 & & \\
\hline 30 & & & & 0.720 & & \\
\hline 27 & & & & 0.718 & & \\
\hline 29 & & & & 0.670 & & \\
\hline 28 & & & & 0.639 & & \\
\hline 32 & & & & & 0.741 & \\
\hline 31 & & & & & 0.684 & \\
\hline 34 & & & & & 0.681 & \\
\hline 35 & & & & & 0.669 & \\
\hline 33 & & & & & 0.661 & \\
\hline 36 & & & & & 0.469 & \\
\hline 42 & & & & & & 0.729 \\
\hline 38 & & & & & & 0.725 \\
\hline 41 & & & & & & 0.708 \\
\hline 39 & & & & & & 0.669 \\
\hline 37 & & & & & & 0.634 \\
\hline 40 & & & & & & 0.604 \\
\hline \%ofvariance 50.832 & 49.867 & 56.052 & 53.014 & 49.566 & 43.058 & 46.187 \\
\hline Eigenvalue $\quad 3.050$ & 2.992 & 3.363 & 3.181 & 2.974 & 2.583 & 2.771 \\
\hline
\end{tabular}

Loading smaller than o.3o omitted. The sample consisted of 500 of Officer/Personnel Educator in 9 Subdistrict

To synthesis the developing guidelines for raising up the quality enhancing Thai education policy reform according to Bueng Kan Primary Educational Service Area Office are assessed with the Questionnaire on Thai Education Policy Reform (QTEPR).

Table 7: The Scale Mean, Item Mean, Standard Deviation, Variance, Cronbach Alpha Reliability, and F-test for the Five Scales of the QTAPR

\begin{tabular}{|c|c|c|c|c|c|c|}
\hline Scale & $\begin{array}{l}\text { Scale } \\
\text { mean }\end{array}$ & $\begin{array}{l}\text { Item } \\
\text { mean }\end{array}$ & $\begin{array}{l}\text { S.D. } \\
\text { (Scale } \\
\text { Mean) }\end{array}$ & Variance & $\begin{array}{l}\text { Alpha- } \\
\text { reliability }\end{array}$ & F-test \\
\hline $\begin{array}{l}\text { Education Reform policy } \\
\text { (EPR) }\end{array}$ & 24.170 & 3.453 & 3.790 & 14.366 & 0.822 & $10.260 * * *$ \\
\hline $\begin{array}{l}\text { Guidelines Raising up Quality } \\
\text { (GRQ) }\end{array}$ & 23.848 & 3.407 & 4.005 & 16.041 & 0.842 & $10.881 * * *$ \\
\hline $\begin{array}{l}\text { Educational Instructive } \\
\text { Integration (EII) }\end{array}$ & 24.608 & 3.515 & 3.319 & 11.149 & 0.680 & $12.882 * * *$ \\
\hline Right Political Asylum (RPA) & 25.212 & 3.602 & 4.386 & 19.234 & 0.828 & $5.311 * * *$ \\
\hline Material/Technology & 25.348 & 3.621 & 4.345 & 18.885 & 0.828 & $4.895^{* * *}$ \\
\hline
\end{tabular}

$\mathrm{N}=500,{ }^{*} \rho<0.05,{ }^{* *} \rho<0.01,{ }^{* * *} \rho<0.001$ 
As each scale has seven items, the minimum and minimum scores for each scale would be 7 and 35 . Internal consistency (Cronbach alpha coefficient) and the mean correlations were obtained. The scale means is ranged from 23.848 (Guidelines Raising up Quality: GRQ) scale to 25.348 (Material/Technology Environment: MTE) scale, the item means ranged from 3.407 to 3.621, Standard Deviation with the scale mean is ranged from 3.319 to 4.386 , Variance is ranged from 14.366 to 19.234 , Cronbach Alpha Reliability is ranged from 0.680 to 0.842 , and F-test is ranged from $4.895(p<.001)$ to $12.882(p<.001)$ for the five scales of the QTAPR. On the whole, these results are acceptable although somewhat lower than obtained previously validation samples.

Table 8: Scale Intercorrelation Circumplex Nature for the QTPAR

\begin{tabular}{llllll}
\hline & EPR & GRQ & EII & RPA & MTE \\
\hline EPR & & & & \\
GRQ & $0.539 * * *$ & & & \\
EII & $0.541^{* * *}$ & $0.644 * * *$ & & \\
RPA & $0.287 * * *$ & $0.187 * *$ & $0.432 * * *$ & & \\
MTE & $0.231 * * *$ & $0.161 *$ & $0.369 * * *$ & $0.760 * * *$ & \\
\hline$N=500,{ }^{*} \rho<.05, * * \rho<.01, * * * \rho<.001$, Correlations are significant (2-tailed). &
\end{tabular}

The synthesis of the developing guidelines for raising up the quality enhancing Thai education policy reform according to the 35-item Questionnaire on Thai Education Policy Reform (QTAPR) are valid and reliable with the Cronbach alpha reliability ( $\alpha=0.684-0.842)$, the correlation is significant at the 0.001 level for the intercorrelation circumplex nature was analyzed, and the factor loading analysis show from 0.435 in Item 19 to 0.789 in Item 19 that factor loading greater than 0.30 (which is the minimum value conventionally accepted as meaningful in factor analysis), and $82 \%$ of the 500 officers and personnel educators' opinions who need to claim from the government policy acceleration on solving problems on material and technology environment $(\bar{x}=3.621)$.

Table 9: Factor Loading Analysis for the QTPAR

\begin{tabular}{llllll}
\hline Item No. & EPR & GRQ & EII & RPA & MTE \\
\hline 3 & 0.764 & & & \\
2 & 0.739 & & & \\
5 & 0.737 & & & \\
6 & 0.712 & & & \\
1 & 0.706 & & & \\
7 & 0.485 & & & \\
12 & & 0.766 & & \\
11 & & 0.746 & & \\
8 & & 0.714 & & \\
9 & & 0.706 & & \\
10 & & 0.706 & & \\
14 & & 0.669 & & \\
13 & & 0.485 & & & \\
16 & & & 0.789 & \\
17 & & & 0.766 & \\
18 & & & & \\
\hline
\end{tabular}




\begin{tabular}{|c|c|c|c|c|c|}
\hline 15 & & & 0.710 & & \\
\hline 20 & & & 0.523 & & \\
\hline 21 & & & 0.495 & & \\
\hline 19 & & & 0.435 & & \\
\hline 26 & & & & 0.739 & \\
\hline 27 & & & & 0.709 & \\
\hline 25 & & & & 0.703 & \\
\hline 23 & & & & 0.699 & \\
\hline 24 & & & & 0.692 & \\
\hline 22 & & & & 0.690 & \\
\hline 28 & & & & 0.680 & \\
\hline 33 & & & & & 0.742 \\
\hline 32 & & & & & 0.734 \\
\hline 34 & & & & & 0.733 \\
\hline 31 & & & & & 0.708 \\
\hline 29 & & & & & 0.692 \\
\hline 35 & & & & & 0.669 \\
\hline 30 & & & & & 0.629 \\
\hline \% of Variance & 48.951 & 51.476 & 36.254 & 49.260 & 49.295 \\
\hline Eigenvalue & 3.427 & 3.603 & 2.549 & 3.448 & 3.450 \\
\hline
\end{tabular}

Loading smaller than 0.30 omitted. The sample consisted of 500 of Officer/Personnel Educator in 9 Subdistrict

According to the right student's asylum ( $\bar{x}=3.602$ ), education policy reform ( $\bar{x}=3.515$ ), guidelines raising up quality ( $\bar{x}=3.453$ ), and educational instructive integration $(\bar{x}=3.407)$. The determination efficient predictive $\left(\mathrm{R}^{2}\right)$ values indicated that $82 \%$ of the 500 officers and personnel educators' opinions who need to claim from the government policy acceleration on solving problems from 5 aspects of assessments for small schools to the small schools in the Bueng Kan Primary Educational Service Area Office, respectively.

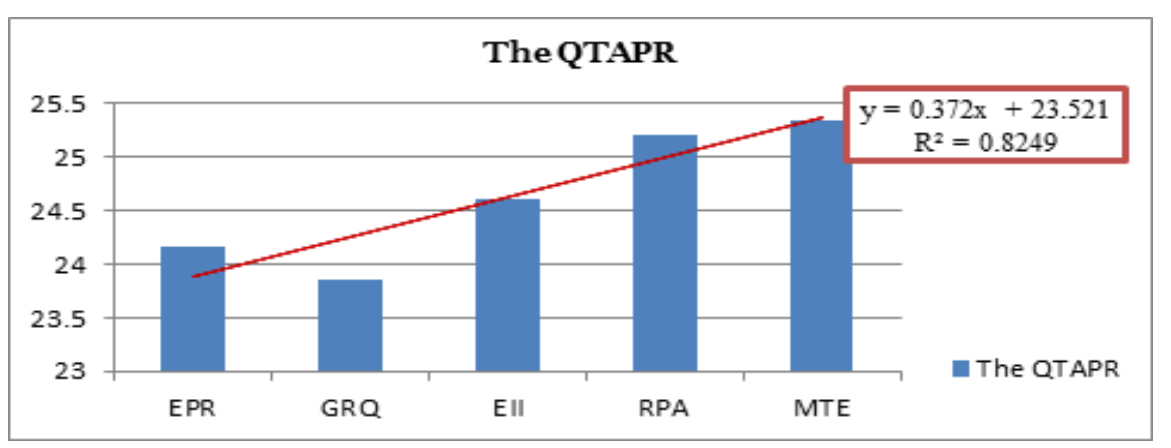

Fig. 5: The pictorial comparisons between five scales of the Thai education reform policy to the guidelines for raising up and developing effective educational organization in small schools' spread to the dissolution of local schools' crisis administration

Because there are the education reform policies by the Ministry of Education for a long time although the Ministry of Education has the policy to reform education but there has not been any change in the academy for students' and teachers' instruction and the guidelines raising up quality is too very poor on the efficiency and effective plan for supporting the small schools. The small schools should be urgently developed and improved before these schools are spreader to dissolution before the small 
schools will be dissolved according to government policy that will affect the change of education to students and youth in rural areas by governances, possibly.

On the whole, the internal consistency by Cronbach alpha reliability of the QTAPR version in this study was determined. In general, the circumplex nature of the QTAPR has been confirmed. It appears that the items had factor loadings greater than 0.30 with their a priori scales, and hence, the results lend support to the factorial validity of the QTAPR, significantly. These results from Tables 7, 8, and 9 suggest that the QTAPR is a reliable instrument for use in small schools' instructional environments, which was considered satisfactory for further use in this study.

To measure Officers'/Personnel Educators' perceptions of the teachers' and students' creative thinking abilities of their instruction in their classes to the small-size schools in Bueng Kan Primary Educational Service Area Office. Using internal consistency (Cronbarch alpha coefficient) was assessed. The results reported in Table 10.

Table 10 reported on the 10 -item Teacher-Student Creative Thinking Ability (TSCTA) in terms of the total mean as 35.684 , the average mean score as 3.566 , the standard deviation with the total mean as 6.141, the variance of data as 37.719, the F-test as 11.679 and significant at the level of .001 . The internal consistency (Cronbach alpha reliability) for the TSCTA had a value of 0.859 which was considered satisfactory for further use in this study.

Table 10: The Scale Mean, Item Mean, Standard Deviation, Variance, Cronbach Alpha Reliability, and F-test for the scale of the TSCTA

\begin{tabular}{|c|c|c|c|c|c|c|}
\hline Item No. & $\begin{array}{l}\text { Total } \\
\text { mean }\end{array}$ & Mean & $\begin{array}{l}\text { Std. } \\
\text { Deviation }\end{array}$ & Variance & a-reliability & F-test \\
\hline Item 1 & - & 3.714 & 0.924 & - & - & - \\
\hline Item 2 & - & 3.632 & 0.939 & - & - & - \\
\hline Item 3 & - & 3.724 & 0.945 & - & - & - \\
\hline Item 4 & - & 3.634 & 0.886 & - & - & - \\
\hline Item 5 & - & 3.478 & 0.922 & - & - & - \\
\hline Item 6 & - & 3.484 & 0.889 & - & - & - \\
\hline Item 7 & - & 3.452 & 0.949 & - & - & - \\
\hline Item 8 & - & $3.55^{\circ}$ & 0.906 & - & - & - \\
\hline Item 9 & - & 3.596 & 0.917 & - & - & - \\
\hline Item 10 & - & 3.400 & 0.972 & - & - & - \\
\hline Total & 35.684 & 3.566 & 6.141 & 37.719 & 0.859 & $11.679^{* * *}$ \\
\hline
\end{tabular}

Associations between the officers/personnel educators' perceptions of the factors on efficient public sector administrative management with teacher-student creative thinking abilities, it was also considered important so investigated associations the OPSs' perceptions were selected for an evaluation and assessment instruments suitable for testing, the fourth research objective was required. Using the inference statistic with the average mean score scales of the FEPSM and the TSCTA with the simple correlation values $(r)$ are reported in Table 11 which show significant correlations $(p<0.05)$ between the officers/personnel educators' perceptions of the (FEPSM) to the TSCTA scale all of seven scales. 
Table 11: Associations between FEPSM Scales and TSCTA in Small Schools in terms of Simple Correlation (r), Multiple Correlation, Standardized Regression Weight Validity ( $\beta$ ), Multiple Correlation (R), and Determination Efficient Predictive Value $\left(\mathrm{R}^{2}\right)$

\begin{tabular}{|c|c|c|c|}
\hline Scale & Mean & $\begin{array}{l}\text { Simple } \\
\text { Correlation (r) }\end{array}$ & $\begin{array}{l}\text { Standardized } \\
\text { Regression Weight } \\
\text { Validity }(\beta)\end{array}$ \\
\hline Change Management & 3.290 & $0.194^{* *}$ & $0.114^{*}$ \\
\hline Strategy/Risk Changes & $3 \cdot 302$ & $0.173^{*}$ & $0.169^{*}$ \\
\hline Efficiency/Effective Plan by & 3.295 & $0.188^{* *}$ & $0.181^{* *}$ \\
\hline Government & 3.271 & $0.186^{* *}$ & $0.164^{* *}$ \\
\hline Leadership Change & 3.322 & $0.171^{*}$ & $0.145^{*}$ \\
\hline $\begin{array}{l}\text { Service Recipients/Stakeholders } \\
\text { Development Personnel }\end{array}$ & $3 \cdot 375$ & $0.181^{* *}$ & $0.178^{* *}$ \\
\hline Characteristic Organization & 3.381 & $0.128^{*}$ & $0.121^{*}$ \\
\hline The TSCTA & 3.556 & & \\
\hline Multiple Correlation (R) & & \multicolumn{2}{|c|}{$0.631 * *$} \\
\hline Determination Efficient Predictiv & $\left(\mathrm{R}^{2}\right)$ & \multicolumn{2}{|c|}{$0.398^{* *}$} \\
\hline
\end{tabular}

The correlations between the mean average scores of the FEPSM on seven scales and the TSCTA were associated. The TSCTA creative thinking abilities among seven scales of the FEPSM were positive relationships significantly when using a simple correlation analysis $(r)$ that ranged from $0.128(\mathrm{p}<.05)$ on Characteristic Organization scale to $0.194(\mathrm{p}<.01)$ on Change Management scale. In regression analysis, it has found that, the standardized regression validity $(\beta)$ was positive validity of the independent variables (FEPSM scales) and the dependent variable (TSCTA) that ranged from 0.114 $(\mathrm{p}<.05)$ to $0.181(\mathrm{p}<.01)$, significantly. The determinant predictive efficiency $\left(\mathrm{R}^{2}\right)$ value indicated that $40 \%\left(\mathrm{R}^{2}=0.398, \mathrm{p}<.01\right)$. It meanwhile, $40 \%$ of the Officers/Personnel Educators are able to predict the associations of seven factors that consist of the change of educational administrative management with the strategy and risk changes are successes with the efficiency and an effective plan by the Thai government.

To associate between the perceptions of the officers' and personnel educators' developing guidelines for raising up the quality enhancing Thai education policy reform and the teachers' and students' creative thinking abilities in instructional classroom environments of the small schools in the Bueng Kan Primary Educational Service Area Office.

The government policy reform plan shows little understanding of the problems or people of those rural areas that make up the majority of the country. It also fails to provide the initiatives, policies or reforms that are needed to achieve these goals. Given the potential for the Officers/Personnel Educators of the Thai education policy reform with the teacher-student creative thinking abilities with the QTAPR scales and the TSCTA in the small-sized classroom qualities were explored to determine their relationship with the Officers/Personnel Educators' perceptions of teachers' and students' instructions' to their creative thinking abilities.

It has found that the results for this simple correlation are positive relationships between the five scales of the QTAPR and the TSCTA scale and ranged from $0.104(\mathrm{p}<.05)$ to $0.291(\mathrm{p}<.01)$, that corrective, significantly. In terms of the Standardized Regression Weight Validity $(\beta)$ that have been standardized 
so that the variances of dependent (the TSCTA scale) and independent variables (QTAPR of five scales) are ranged from $0.147(\mathrm{p}<.05)$ to $0.249(\mathrm{p}<.01)$, significantly.

Table 12: Associations between QTAPR Scales and TSCTA in Small Schools in terms of Simple Correlation (r), Multiple Correlation, Standardized Regression Weight Validity ( $\beta$ ), Multiple Correlation (R), and Determination Efficient Predictive Value $\left(\mathrm{R}^{2}\right)$

\begin{tabular}{llll}
\hline Scale & Mean & $\begin{array}{l}\text { Simple } \\
\text { Correlation }(\mathrm{r})\end{array}$ & $\begin{array}{l}\text { Standardized } \\
\text { Regression Weight } \\
\text { Validity }(\beta)\end{array}$ \\
\hline Education Reform policy & 3.453 & $0.104^{*}$ & $0.147^{*}$ \\
Guidelines Raising up Quality & 3.407 & $0.198^{* *}$ & $0.192^{*}$ \\
Educational Instructive Integration & 3.515 & $0.291^{* *}$ & $0.249^{* *}$ \\
Right Political Asylum & 3.602 & $0.135^{*}$ & $0.210^{*}$ \\
Material/Technology Environment & 3.621 & $0.264^{* *}$ & $0.224^{* *}$ \\
\hline The TSCTA & 3.556 & & $0.602^{* *}$ \\
\hline Multiple Correlation (R) & & & $0.362^{* *}$ \\
\hline Determination Efficient Predictive Value $\left(\mathrm{R}^{2}\right)$ & & \\
$N=50 O,{ }^{*} p<.05,{ }^{* *} p<.01,{ }^{* * *} p<.001$ & &
\end{tabular}

This was the correlation between the variable's values and the best predictions that can be computed linearly from the predictive variables. It has found that the Multiple Correlation $(R=0.602, p<.01)$, correlative variables, significantly. The main purpose is either the prediction of future outcomes or the testing of the fifth research objective and hypothesis. The $R^{2}$ value indicates of 0.362 ( $\left.<<.01\right)$, it meanwhile, $36 \%$ from the 500 sample size is opinions on the educational policy reform to the teachers and students who should be made senses of their creative thinking abilities in their instructional classroom environments in the small schools.

\section{CONCLUSION AND DISCUSSIONS}

This research studies that following in the five research objectives. To describe the factors on efficient public sector management at the current conditions, problems, and needs of the administrations of small schools. Using the 42-item Factors on Efficient Public Sector Management (FEPSM) Questionnaire in seven scales with the perceptions of the Officers/Personnel Educators are analyzed, and valid and reliable with internal consistency Cronbach alpha reliability (ranged from 0.728 to 0.842 ), the intercorrelation circumplex nature as correlation is significant at the 0.001 level from the scale in next scales, and factor loading analysis (ranged from 0.469-Item 36 to 0.808-Item 2) is greater than 0.30 (which is the minimum value conventionally accepted as meaningful in factor analysis) ${ }^{[18]}$.

The sample size's responses as $60 \%$ of the 500 officers and personnel educators' perceptions who need to develop the characteristic $(\bar{x}=3.381)$ of small school organization at the first. According to the development personnel $(\bar{x}=3.375)$, service recipients/stakeholders $(\bar{x}=3.322)$, strategy and risk changes ( $\bar{x}=3.302$ ), change management $(\bar{x}=2.290)$, leadership change $(\bar{x}=2.290)$, and efficiency and effective plan by the government $(\bar{x}=2.290)$ was analyzed on the first research objective on the factors on efficient public sector management at the current conditions, problems, and needs of the administrations of small schools in the Bueng Kan Primary Educational Service Area Office are assessed with the Factors on Efficient Public Sector Management (FEPSM) Questionnaire, respectively.

617 JECET; September 2020- November 2020; Sec. A; Val.9. №.4, 60I-621. DOI:10.24214/jecet.A.9.4.60121. 
The synthesis was described the developing guidelines for raising up the quality enhancing Thai education reform policy according to the 35-item Questionnaire on Thai Education Reform policy (QTAPR) are valid and reliable with the Cronbach alpha reliability $(\alpha=0.684-0.842)$, the correlation is significant at the 0.001 level for the intercorrelation cricumplex nature was analyzed, and the factor loading analysis show from 0.435 in Item 19 to 0.789 in Item 19 that factor loading greater than 0.30 (which is the minimum value conventionally accepted as meaningful in factor analysis), and $82 \%$ of the 500 officers and personnel educators' opinions who need to claim from the government policy acceleration on solving problems on material and technology environment $(\bar{x}=3.621)$, according to right political asylum ( $\bar{x}=3.602$ ), education reform policy ( $\bar{x}=3.515)$, guidelines raising up quality $(\bar{x}=3.453)$, and educational instructive integration $(\bar{x}=3.407)$ to the small schools in Bueng Kan Primary Educational Service Area Office, respectively.

Associations the officers' and personnel educators' perceptions of the teachers' and students' creative thinking abilities in instructional classroom environments of the small schools in the Bueng Kan Primary Educational Service Area Office with the 10-item Teacher-Student Creative Thinking Ability (TSCTA) scale is valid and reliable for the Cronbach alpha reliability $(\alpha=0.856)$ and the mean average score as 3.566 that further use satisfactory in this study.

Associations between the factors on efficient public sector management (FEPSM) perceptions and the teachers' and students' creative thinking abilities (TSCTA) in instructional classroom environments of the small schools in the Bueng Kan Primary Educational Service Area Office is a positive correlation between the independent variables (FEPSM) and dependent variable (TSCTA) relationships with Simple Correlation ( $\mathrm{r}=0.128-0.194 ; p<.05$, positive significantly). The Standardized Regression Weight Validity $(\beta=0.114-0.181 ; \mathrm{p}<.05$, predictive value, significantly). The multiple correlations ( $\mathrm{R}$ $=0.631, \mathrm{p}<.01$, correlative variables, significantly $)$. The determinant predictive efficiency $\left(R^{2}=0.398\right.$, $p<.01$ ), it meanwhile, $40 \%$ of the Officers/Personnel Educators are able to predict the associations of seven factors that consist of the change of educational administrative management with the strategy and risk changes are successes with the efficiency and effective plan by Thai's government administrative management to teachers and students make sense of their creative thinking abilities in their instructional classroom environments ${ }^{[20]}$.

Associations between the perceptions of the officers' and personnel educators' developing guidelines for raising up the quality enhancing Thai education reform policy (QTAPR-independent variable) in five scales and the teachers' and students' creative thinking abilities (TSCTA-dependent variable) in the instructional classroom environments at the Office of Bueng Kan Primary Education Service Area are a positive correlation between the independent and dependent variables relationships with the simple correlation ( $\mathrm{r}=0.104-0.291 ;(p<.05)$, significantly, and positive correlation, directly). The Standardized Regression Weight Validity $(\beta=0.147-0.249 ; \mathrm{p}<.05$, predictive value, significantly).

The multiple correlations $(\mathrm{R}=0.602, \mathrm{p}<.01$, and correlative variables, significantly). The determinant predictive efficiency $\left(R^{2}=0.362, p<.01\right.$, predictive correlation, significantly), it meanwhile, $36 \%$ of the Officers and Personnel Educators are able to predict the Thai education reform policy by the government of the material instruments and technology for learning classroom environments are associated with five factors that consist of the education reform policy, guidelines raising up quality, educational instructive integration, right political asylum are successes with the efficiency and effectiveness of teachers' and student' creative thinking abilities who are able to make sense of their creative thinking abilities in their instructional classroom environments.

The educational instructive integration is too very necessity for teachers and students in their classes, because there are the education reform policies by the Ministry of Education for a long time although 
the Ministry of Education has the policy to reform education but there has not been any change in the academy for students' and teachers' instruction, and the guidelines raising up quality is too very poor on the efficiency and an effective plan for supporting the small school. The small schools should be urgently developed and improved before these schools are spreader to dissolution before the small schools will be dissolved according to the government's policies that will affect the change of education to students and youth in rural areas by governances, possibly.

Development of students' creativity in the classroom is created a compassionate, accepting environment that is presented with students' ideas and encourages autonomy. Teachers and students' reword assignments to promote creative thinking to give students direct feedback on their creativity for helping students know when it's appropriate to be creative. Creative thinking involves students learning to generate and apply new ideas in specific contexts, seeing existing situations in a new way, identifying alternative explanations, and seeing or making new links that generate a positive outcome which their teachers ${ }^{[19]}$.

If the governances need to reform of primary education, the $40 \%$, and $36 \%$ of the 500 Officers/Personnel Educators think that the primary small schools must be reformed on the material instructional instruments and using the technology in their instructional classroom environment to creative thinking abilities as the first. These are affected by students' right students' asylum education from their local schools to the city schools. Therefore, teachers should be able to educational instructive integration of the administrative management is failed with the government reform policy. These are indicated that the guidelines raising up quality are provided.

Here are five ways to improve education in Thailand:

1. Several educations in Thailand have abolished their school fees. Each time, the move has triggered a large increase in the rural primary small school enrollment.

2. It's been proven that malnourished children learn poorly. Providing food during school will alleviate these children's hunger during class as well as encourage regular school attendance. School lunch programs have been shown to increase learning achieved scores, student concentration, and general achievement to have an immediate positive impact on learning.

3. A parent's investment in education is crucial for the success of their children. The funding budgets are illiterate and do not have the awareness necessary to improve both their living conditions and those of their children. Providing parents with information on the value of education will be crucial to increasing and maintaining school enrollment.

4. Investing in test scores and achievement is no longer a useful way to focus on education, according to the O-NET, GAT/PAT, NIETS, and the PISA. A new educational model should combine traditional content with important financial, health, and administrative skills. Students should practice teamwork, leadership, and critical thinking. They should also gain exposure to entrepreneurship projects such as identifying and exploiting ideas. This shift away from standardized learning will prepare students to make a positive impact on their communities.

5. Computer-assisted learning will inevitably improve education in developing education in small schools and enhance the educational experience of both teachers and students. The computers should have age-appropriate learning software and a technically the educated staff that knows how to maintain them to improve education in their classroom learning will continue to encourage student enrollment, and most importantly, will ensure that children stay in school and learn more while they are there. 


\section{ACKNOWLEDGMENTS}

Authors acknowledge the National Research Council of Thailand (NRCT), the National Research Project of the Research and Development Institute of Udon Thani Rajabhat University (NRP-UDRU), for financial support, and Prof. Dr. Toansakul T. Santiboon (1269383) of the Research and Postgraduate Administrator (18/106935), Queen's University Belfast, Northern Ireland, UK, for their co-operation in the maintenance for their support.

\section{REFERENCES}

1. Bangkok Post, Reforms needed to fix Thai schools. Ministry of Education. March 20, 2020. http://www.en.moe.go.th/enMoe2017/index.php/articles/313-reforms-needed-to-fix-thaischools

2. Ministry of Education, Reform Thailand's failing social institutions. February 11, 2019 https://www.bangkokpost.com/opinion/opinion/1626338/reforms-needed-to-fix-thai-schools

3. Ministry of Education, Education Ministry gets prepared for start of new academic year in July. National News Bureau of Thailand. May, 2020.

4. U.Pinasa,. Teachers \& School Quality Program: TSQP. The Office of Basic Educational Commission (OBEC), Ministry of Education.2020, Retrieved from https://www.kroobannok.com/87464

5. S. Buasai, Teachers \& School Quality Program, 2020. Fund Manager for Educational Equality (FMEE). Retrieved from https://www.kroobannok.com/87464

6. W. Phanish, Improve the quality of teaching in rural schools, 2020. Retrieved from https://www.kroobannok.com/87464

7. Education Management Information System (EMIS), Office of Buengkan Primary Education Service Area, (2019). Basic information of the school under the Office of Buengkan Primary Education Service Area. Retrieved on 10 June 2019 from https://data.boppobec.info/emis/school.php?Area_CODE=3801

8. P. Padkuntod, Thai education system fails to pass the test, says UNESCO report: Paper encourages schools to prepare students for a fast-changing world. Bangkok Post. November 18, 2017. https://www.bangkokpost.com/opinion/opinion/1363115/thai-education-system-fails-topass-the-test-says-unesco-report

9. N. Teepasuwan, Amendments to laws and regulations related to private schools. Primary of the Ministry of Education of Thailand, 2019. Thai Post. Retrieved on 27 November 2019. From https://www.thaipost.net/main/detail/51261

10. S. Yodsala, New small school management: Survival or alternatives, 2018. Ph.D. Thesis. Department of Educational Administration. Mahasarakham University.

11. UNECO Digital Library. (2016). The Privatization of education in developing countries: evidence and policy implications. March 3, 2016. https://unesdoc.unesco. org/ark:/ 48223/ pf0000243824 
12. Ministry of Education, Reforms needed to fix Thai schools. February 11, 2019. http://www.en.moe.go.th/enMoe2017/index.php/articles/313-reforms-needed-to-fix-thaischools

13. Ministry of Education, Basic Education Core Curriculum B.E. 2551 (2008) Revised to the Basic Education Core Curriculum B.E. 2060 (2017) and Montessori Teaching 20 Jan 2018. January 20, 2018. https://www.techawitschool.ac.th/basic-education-core-curriculum-b-e-2008revised-b-e-2017-and-montessori-teaching-20-jan-2018/

14. Education Management Information System (EMIS), Office of Buengkan Primary Education Service Area, (2019). Basic information of the school under the Office of Buengkan Primary Education Service Area. Retrieved on 10 June 2019 from https://data.boppobec.info/emis/school.php?Area_CODE=3801

15. The Office of Buengkan Primary Education Service Area. (2018). The development of operating guidelines for small school network groups under the Bueng Kan Primary Education Service Area Office, Sakon Nakhon Graduate School Journal. July 6, 2018. https://so02.tcithaijo.org/index.php/SNGSJ/article/view/73833

16. The Royal Thai Government Gazette, Announcement of the Prime Minister's Office regarding the appointment of civil servants (PDF), 136 (Special 242 Ngor). 12. September 28, 2019. http://www.ratchakitcha.soc.go.th/DATA/PDF/2562/E/242/T_0006.PDF

17. The Royal Thai Government Gazette. (2019). Act Establishing Changwat Bueng Kan, BE 2554 (2011) (PDF). 128 (18 A): 1. 22 March 2011. http://www.ratchakitcha.soc. go.th/DATA /PDF/2554/ A/018/1.PDF

18. T. Santiboon, T. (2017). Appropriating characteristics of the 21 st century teachers to transform of the Thailand 4.0 policies. African Journal of Pedagogy and Curriculum, 2017, 4, 1, 48-64

19. T. Santiboon, Students' perceptions of their classroom learning environment inventories in the 21 st century in physics laboratory according to enhance creative thinking abilities toward science in upper secondary education under Office of Khon Kaen Provincial Private Education Commission. The 7th International Conference on Sciences and Social Sciences 2017: Innovation Research to Stability, Prosperity and Sustainability. Rajabhat Maha Sarakham University. 11-12 January 2018

20. C. Chanthala, T. Santiboon \& K. Ponkham, Instructional designing the STEM education model for fostering creative thinking abilities in physics laboratory environment classes. AIP Conference Proceedings 1, 2017,923, 030010 (2018).

\section{* Corresponding Author: Teerapol Pengchan}

Development of Educational Administration, Faculty of Education,

Udon Thani Rajabhat University, Thailand

Date of publication on line 02.09.2020 